Mid-American Review of Sociology

Thompson, E.P.

1963 The Making of the English Working Class. New York: Vintage.

1978 The Poverty of Theory. New York: Monthly Review Press. Tilly, Charles

1978 From Mobilization to Revolution. Reading, MA: AddisonWesley.

Tilly, Charles and Louise Tilly

1981 Collective Action and Class Conflict. Beverly Hills, CA: Sage.

Tilly, Charles, Louise Tilly, and R. Tilly

1975 The Rebellious Century. Cambridge, MA: Harvard University Press.

Traugott, Mark

1985 Armies of the Poor: Determinants of Working-Class Participation in the Parisian Insurrection of June 1848. Princeton, N.J.: Princeton University Press.

Wright, Erik O.

1984 "A General Framework for the Analysis of Class Structure." Politics and Society 13:383-423.

1985 Classes. London: Verso Books, 1985.

\section{WHAT'S NEW ABOUT THE "NEW SOCIAL MOVEMENTS"? CONTINUITIES AND DISCONTINUITIES WITH THE SOCIALIST PROJECT}

\author{
Peter Kivisto \\ Augustana College
}

Mid-American Review of Sociology, Vol. XI, No. 2:29-44

Since the 1960s, social theorists have sought to explicate factors that contributed to the emergence of the New Left in North America and Western Europe and to the "new social movements" that arose during this tumultuous decade (see, for example, Alberoni, 1984; Birnbaum, 1969; Gamson, 1975; Gorz, 1973; Gouldner, 1979; Habermas, 1970 and 1975; Jenkins, 1986; Klandermans and Oegema, 1987; Oberschall, 1978; Offe, 1984 and 1985; Tilly, 1978; Touraine, 1971a, 1971b, and 1981; Useem, 1975). There are, as Cohen (1983:97) suggests, "compelling reasons for a renewed reflection on the significance and potentials of social movements." In no small part, this is because these movements served to dispel the conviction that advanced industrial societies had arrived at a stage that marked the "end of ideology," as they reflected instead conflictual tendencies in those societies. This paper explores questions concerning the relationship of these movements to socialism. It does so by reviewing issues raised both in theoretic discourse and in concrete instances of these new contestatory actors.

Two approaches to the study of social movements can be distinguished: resource mobilization theory (Jenkins, 1985; McAdam, 1982; McCarthy and Zald, 1973; Oberschall, 1973; Perrow, 1979) and what might be defined, albeit imprecisely and in a more generalized sense, as critical theory. The former emerged out of and in response to collective behavior theory. While there are significant variations within the general theoretic framework, those working within its parameters agree that social movements are rational, the underlying structural sources of conflict are ubiquitous features of contemporary societies, and that movement mobilization occurs with the proper confluence of resources, organization, and opportunities (Jenkins, 1983:528). These domain assumptions are intended to contest earlier psychologistic theories that saw social movements as pathological evidences of strain (e.g., Smelser, 1963). Resource mobilization theory implicitly argues that social movements can be far more pervasive than earlier theories would suggest. 
As the recent efflorescence of research into contemporary social movements indicates, resource mobilization theory has succeeded in providing new insights into such issues as who joins a movement and why (the debates over the "free-rider" dilemma being part of this particular topic), the role of professionals vis-a$v i s$ grassroots activists, the significance of various kinds of material and cultural resources, and the duration of movements. It has chosen to focus attention on the internal workings of social movements and on the immediate environment in which they exist. It has not sought, in any significant degree, to locate these movements in terms of macro-social patterns of cultural, political, and social change. Furthermore, it has not attempted to distinguish among types of movements, its framework being seen as suitable to the study of progressive, left-of-center movements and reactionary, rightist movements, as well as those that defy such political classification (holistic health, natural foods, anti-smoking, etc.).

As a consequence, any effort to address the questions posed in the title of this paper cannot be adequately met by a major reliance on resource mobilization theory. However, it can be useful in adding analytic rigor to the discussions of various critical theorists. It is this latter group that has sought to locate the distinctive and novel role of various contemporary social movements as vehicles for social change. The movements in question are a congeries of organized dissent: students, women, environmentalists, peace activists, ethnic and racial minorities, and others (Cohen, 1985; Eder, 1985). They are seen as progressive, leftist challengers of central features of advanced industrial society and of existing networks of power and material resource distribution. While many critical theorists offer a more nuanced assessment of these movements, there is general agreement with the thrust of Touraine's (1981:9) claim that, "For the first time, social movements are becoming the main actors of society:. . the principal agents of history."

Of crucial importance in assessing this claim is an ability to adequately contextualize these movements within the parameters of advanced industrial societies. Much of the discussion has been posed in terms of post-capitalist, post-modern, post-scarcity, or, most commonly, post-industrial society. These conceptualizations, however varied, share several things in common. In the first place, they treat the economic realm as increasingly intertwined with and subservient to the polity. Second, technological developments have served to transform the workplace and have had a profound impact on the class structure. Third, bureaucratization has progressed and new modes of administrative control and domination have emerged.
Consequently, economic class divisions are no longer as significant as they once were and class conflict yields to new modes of conflict located chiefly in the civic and cultural realms. The underlying assumption in these formulations is that a radical rupture with the immediate past either has occurred or is occurring.

Discontinuity is achieved by definitional fiat: it is no longer necessary to comprehend precisely how the past, in Marx's (1972:437) words, "weighs like a nightmare on the brain of the living." The muddled contingencies of history, which necessitate an appreciation of changes characterized by both continuity and discontinuity, are circumvented. In this sense, one can "bid adieu to the working class" (Gorz, 1982) and offer in its place novel historical agents. This mode of conceptualization (though not critical theory's conclusions) is not essentially different from functionalism's modernity thesis. In its post-Parsonian, "neofunctionalist" form, modernity has been defined as the expansion of differentiation and inclusion and the very movements under consideration here are defined, ipso facto, as anti-modern (cf., Lechner, 1985).

Preferable, I would argue, is a depiction of the present that recognizes change and persistence. Habermas's (1975) term "late capitalism" can be useful, though the adjective contains a peculiar mixture of analytic rigor and wishful thinking. Perhaps the more useful concept is the one employed throughout this paper: advanced industrial society (Giddens, 1973).

In these terms, what was the "socialist project" during early industrial society and what is its future in advanced industrial society? Socialism, quite simply, arose as a response to the glaring inequities and the degradation of everyday life that was the lot of the newly-emergent working class in the nineteenth century (Abendroth, 1972; Hobsbawm, 1984; Thompson, 1963). It reformulated the defensive challenges to capitalist hegemony of collective actors such as the Luddites by defining the emerging proletariat not simply as an exploited class, but as a revolutionary class as well. Socialism offered a future-oriented rationale for action in place of visions rooted in the reestablishment of traditional lifeworlds.

Marx was particularly hostile to romantic pastoralists (though the early Marx, evident for instance in The German Ideology, was not immune from German Romanticism). His understanding of socialism, which became the dominant interpretation, embraced industrial society while seeking to transcend its domination by capitalism. Socialism explicitly endorsed the process of industrialization and implicitly embraced urbanization and 
rationalization. It offered an alternative vision of industrial society, constituted by the triple goals of freedom, equality, and community. It presented, particularly in its Marxist form, an analysis of the class-based roots of domination and exploitation, developed in predictions about the progressive emiseration of the proletariat and the crisis tendencies of capitalism generated by the falling rate of profit. Finally, by arguing for the centrality of classes and of class struggle as the key motor of history, it established the theoretical underpinning for revolutionary (or, in some later versions, evolutionary) praxis.

An important consequence of the emphasis on class divisions and class conflict is that other modes of societal dissent and protes are devalued. Indeed, ethnicity and race were treated as mere impediments to the development of class consciousness, and gender issues tended to be ignored. Furthermore, the conviction that the proletariat had a revolutionary historical mission frequently led socialists to fail to appreciate cleavages within the working class and to see, in many instances, worker militancy as defensive attempts to preserve aspects of a threatened past.

By uncritically endorsing industrialization and a productivist ethic, the domination of nature was accepted. What Horkheimer and Adorno (1972) referred to as the "dialectic of Enlightenment" and Alford (1985) has termed the "revenge of nature" was not capable of being conceptualized by a perspective that failed to recognize the limits to economic growth posed by environmental constraints.

Finally, a serious lacuna in Marxist theory was an analysis of the formation of the modern nation-state. While capitalist development constitutes one of the central elements of modernity, of equal importance is the rise of the nation-state (Tilly, 1975). New modalities of political violence and warfare were not adequately explored; neither was the powerful impact of nationalism. Further, this lack of attention to the potential relative autonomy of the state resulted in a failure to understand its role in employing various modes of intervention in an effort to manage the crisis tendencies of capitalism, to enact various entitlement programs designed to redress the most glaring inequities of the system, and to (through the institutionalization of collective bargaining) provide a basis for securing industrial peace between labor and management.

What this suggests is that inherent limitations built into Marxian discourse have a direct impact on efforts to comprehend contemporary developments. Nonetheless, critical theorists have not freed themselves from the rhetoric of Marxian social thought; they are, as Boggs (1986) has suggested, engaged in a "struggle for a post-Marxist discourse.

One indication of this "struggle" involves both categorizing the class structure of advanced industrial societies and indicating the role of classes in producing social change. Several theoretical strands can be identified. First, the approach most rooted in Marxian social theory attempts to more rigorously define the working class. Poulantzas (1975), adopting Marx's definition of the proletariat as the producers of surplus value, of fered a minimalist definition, while others such as Szymanski (1978) of fer more modified and expansive or maximalist definitions. Wright's (1985) comparative research attempts to establish a middle ground between these extremes. In such efforts to determine who is and who is not part of the proletariat, little attention has been devoted to the orthodox Marxist assumption about the historical mission of the proletariat.

This issue has been addressed by those seeking to identify new sectors of the working class that are potentially capable of challenging capitalist hegemony. The effort to update Marx took a novel turn in the work of Mallet (1969). Contending that technological evolution had given birth to a "new working class," he located the new contestatory social actors in the most advanced sectors of the economy. Mallet asserted that high wages and job security, far from muting dissent, served as the basis for challenges far more threatening to capitalism than the demands of bread-andbutter trade unionism. Workers deeply embedded in the new economic system introduced issues related to the control of work and alienation.

Mallet's approach, with its implicitly Leninist depiction of a revolutionary vanguard, is problematic for several reasons. First, it fails to def ine the relationship of the new working class to the rest of the working class. To see it as a vanguard fails to address the fact that the objective interests of this more privileged sector might differ significantly from the rest of the working class. Indeed, the work of Goldthorpe and Lockwood (1963), Mann (1973), and most recently Forms's Divided We Stand (1985) emphasize the cleavages within the working class that make concerted united action difficult, if not impossible. Second, the thesis assumes that we are entering a post-scarcity world, at least for the most skilled and educated sector of the working class. As recent events indicate, this would appear to have been a rather myopic assumption.

Most of the new social movements are principally composed of members of the middle class, who the above-noted theorists fail 
to grapple with due to an adherence to fundamental Marxian assumptions. However, in two somewhat different ways, efforts have been made to provide a class analysis that addresses not simply the significance of the growth of the middle class, but the distinctive location and character of the new middle class (Mills, 1956; Bell, 1973; Bensman and Vidich, 1971), which makes its living by wage earning and, because it is a knowledge class, possesses human capital rather than moneyed capital. The first approach was outlined by Gouldner (1979) in a fusion of an Hegelianized Marxism and Weberian theory. He disputes arguments that the new class should be viewed as benign technocrats, a master class, an old class ally, or servants of power. Rather, he argues, it is a "flawed universal class" (1979:6-7). It pursues its own self-interest, but is capable of acting in the interest of the larger societal totality. The new class may be "the best card that history has presently given us to play." While Gouldner suggests that much necessarily remains ambiguous about this growing and evolving class, he implies that the new social movements will be dominated by participants from it, who will be in various degrees and combinations self-serving and selfless.

Gouldner did not directly address the issue of the new social movements. Touraine (1971a; 1971b; 1981), who perhaps best represents the second approach, has done so. One of the early figures associated with discussions of "post-industrial society," he treats such societies as containing inherently conflictual social relations, which he conceptualizes simultaneously in class terms and in terms of social movements. Regarding the former, he abandons the specificity of the Marxist location of the central manifestation of conflict between the bourgeoisie and the proletariat, but he maintains its portrayal of an essentially dichotomous class structure, depicted in more inclusive and more ambiguous terms. Thus, conflict in contemporary society pits the dominant class against the classe populaire. He conceptualizes the significance of the new social movements in this general framework. The anti-capitalist old Left is dead, but rather than entering into a post-socialist age, a novel socialism, antitechnocratic at its core, is emerging. According to Touraine (1971a), May 1968 is to post-industrial society what 1848 was to industrial society: a sign of the birth of new social movements.

These social movements have genuine transformative potential. They are depicted as capable of steering a course between revolutionary action (which Touraine thinks unrealistic) and reformism. Through the medium of class relations, various dissenting sectors of the classe populaire, including ethnic groups, feminists, consumer activists, anti-nuclear groups, ecologists, and peace activists, have emerged to challenge the dominant class's control of the "field of historicity" (Touraine, 1981). In addition, Touraine tends to treat the working class as another element in this overall matrix. Rejecting the Hegelian notion of systemic contradictions, his analysis of the root causes of dissent underpinning these movements is, in many respects, a not unconventional conflict sociology.

By his estimation, these movements are distinctive in comparison to earlier movements insofar as they have self-reflexive capabilities and are fundamentally rational. The ability of such movements to learn by linking critique and action entails their capacity for self-limiting (i.e., non-revolutionary) challenges to the dominant class. His development of the technique of sociological intervention is predicated on the assumption that these movements must develop by achieving greater self-definition and in locating themselves vis-a-vis the opposition and the societal totality (Touraine, 1981; Kivisto, 1984). Furthermore, though he is not explicit on this point, Touraine seems to suggest that these distinct movements are capable of coalescing into a grand movement of opposition.

There are a number of problems with his formulation. In the first place, Touraine's attempt to conceptualize the new social movements within a bimodal class structure is less than convincing. His conception of class is akin to the theoretical bifurcation between elites and masses, an approach that clearly fails to appreciate the complex nature of the class structure of advanced industrial societies. For instance, it does not account for the complicated relationship between the white collar middle class and the working class.

Regarding the movements themselves, a number of issues need to be raised. First, it might be suggested that--as with resource mobilization theorists--Touraine has an over-rationalized view of the social movements. Second, while aware of the internal fissions contained in each movement, his work tends to downplay them. Sociological intervention is premised on the assumption that such fissions can be overcome. Third, his theory does not provide the basis for adequately distinguishing reformist demands and actions from those that call for, to use Gorz's (1982) terminology, "non-reformist reforms." Fourth, he overlooks differences regarding both concrete interests and operative ideologies that characterize these diverse movements, differences that would impede a coalescence into a unified movement of opposition. Finally, Touraine is not clear about the similarities and differences 
between the newly-emergent socialism and its predecessor, nor, in his empirical studies of the Occitan ethnic revival, the French women's movement, the student movement, or Solidarity, does he provide convincing evidence that socialist ideas are embedded in the consciousness of a significant percentage of movement actors.

It is useful to distinguish Touraine from Offe $(1984 ; 1985)$, who has recently written about the advent of eco-socialism. In contrast to Touraine's "non-teleological" theoretic perspective, Offe explicitly attempts to depict systemic contradictions in contemporary welfare states, which he describes as seeking to promote a commodity mode of production while simultaneously decommodif ying increasingly large arenas of social life. According to him, new forms of social conflict are generated by these contradictions. Offe does not present what Touraine might be characterized as offering: a post-capitalist theory. That is to say, Offe depicts the system contradictions in terms of distinctive features of capitalist economies, and not of industrial societies, per se. In this sense, he remains more of a Marxist than Touraine. On the other hand, he abandons the notions of class actors in the conventional Marxist sense. The class character of the new social movements is more problematic and the linkages between classes and movements is complex. While not altogether clear on this point, he appears to believe that the salience of class identity declines in contemporary societies in the face of competing identities; class no longer holds the privileged position it once did. One cannot, in any simple way, define the new social movements in class terms.

Offe emphasizes two distinctive features of contemporary industrial societies that make them different from the earlier phase of industrial development. Their polities are representative democracies and they are welfare states. They have formalized institutionalized mechanisms for handling dissensus. In this milieu, Offe suggests, while the crisis tendencies of capitalism have been muted, they have by no means disappeared. A number of interconnected questions emerge: (1) Under what circumstances will non-institutional political conflict occur?; (2) What is the relationship between institutional reform and non-institutional change?; (3) Do the new social movements seek to replace representative democracy with participatory democracy or to, in some fashion, integrate the two?; and (4) What are the chances for these movements to succeed? Offe does not provide systematic or comprehensive answers to these queries, but, in a few key instances, his work clearly contrasts with that of Touraine. For instance, he does not believe that these movements will merge into large contestatory movement. He sees them as fragmentary and issue specific. While this might be, in some circumstances, a virtue, one less-than-sanguine scenario that of $\mathrm{fe}(1985: 256)$ describes is "a stand-off confrontation, unproductive of major social changes except for an escalation of repression and violence."

In beginning to explore empirically the relationship between the new social movements and their environments, country-specific differences are evident. One of the central factors underlying perceived differences is the strength or weakness of the traditional socialist Left. Those nations with a strong Leftist presence (including the existence of explicitly socialist or labor political parties) will tend to infuse socialist ideas and ideals into movement rhetoric while those lacking such a presence will not. For instance, a comparison of the British and American women's movements indicates a strong strain of socialist feminism in Britain competing with liberal and radical (i.e. cultural, sexual preference, separatist) feminism, while in the United States socialist feminists are a miniscule component of the overall movement, which has been dominated by liberal feminists. Similarly, the ethnic revival in France--though a very complicated and of ten contradictory phenomenon--contained a strong socialist element, while in the United States it was largely a conservative reaction on the part of the white ethnic groups to the civil rights movement (Smith, 1981).

Boggs (1986) has recently distinguished three region-specific variants of the new social movements: Eurosocialism, American populism, and the Green movement. Eurosocialism, especially in France, Greece, and Spain, speaks most explicitly to the development of a democratic Lef $t$ in contexts where the vestiges of Leninism have lingered longer than elsewhere. It addresses issues of openness and pluralism and, as socialists have assumed power, has been forced to wrestle with issues related to economic growth, fiscal restraint, technocracy, and the like. Eurosocialism was successful in electoral campaigns insofar as it was predicated on a Leftist tradition among voters who, for various reasons, were willing to abandon parties closely associated with the Soviet bloc. It failed once in of ice insofar as it proved incapable of integrating Old Left and New Left concerns and issues.

In the United States, where socialism failed to take root in institutionalized politics, the emergence of an ambiguous populism raises a number of questions. Its concern for the grassroots and for decentralization has led it to focus on the local, even neighborhood, level (Boyte, 1980). As a result, it tends to bypass opportunities to effect change at the national level. When organizational networks have been created, they tend to eschew theoretical critique and the 
creation of a coherent ideology. Thus, ACORN is content to describe itself merely as "anticorporate" and in favor of economic democracy, with its goals being to provide people with "a chance to be rich" and "the right to be free" (Delgado, 1986:202-208). Rather than wrestling with the issue of class, populism tends to bury class analysis (Kann, 1986). It is sufficiently eclectic to have produced a wide variety of movements, but they tend to be more issue-specific than elsewhere and, ultimately, more fragile because they are not grounded in a Left tradition.

The Green Movement, especially in West Germany, most explicitly raises the question of a novel socialism or an ecosocialism (Bahro, 1984; Capra and Spretnak, 1984; Cohen and Arato, 1984; Mewes, 1983; Papadakis, 1984). Here, in microcosm, the fundamental issues that confront the new social movements coalesce. The very name of the movement raises questions about linkages to the past. While "Green" symbolizes the movement in terms of its ecological focus, the color also is the antithesis of the Old Left's "Red" politics. This could suggest either an abandonment of socialism or the incorporation and transcendence of socialism to address new historical circumstances. Within the Greens there are numerous conflicting positions regarding this basic issue, but in general terms it is possible to speak of the split between "fundamentalists" and "realists." The former seek a break not only with socialism and the labor movement, but with industrial society; the latter, in contrast, seek a fusion of socialism with not only ecological issues, but with peace, feminist, and related issues, as well. Tied to this split are a host of other debates that divide movement participants. Among the most important are the following:

(1) The fundamentalists root the ecological crisis in industrialization per se, while the realists depict it as a consequence of the specific dynamics of capitalist industrial society. Thus, while the former, in a manner reminiscent of German Romanticism, seek a return to a pre-industrial organically integrated society, the latter seek to unyoke industrial society from capitalism and, in so doing, to make possible policies aimed at addressing ecologically-dictated limits to growth. The former tend to apocalypticism, while the latter are forced to contend with how to develop, borrowing from Nove (1983), a "feasible socialism." Thus, differing economic critiques have implications for political analyses.

(2) A question is raised about participatory democracy: should it be seen as an alternative to representative democracy or should the objective be to forge a reciprocal relationship between the two? Embracing the former, the fundamentalists are inclined to oppose involvement in institutional politics, unless such involvement is meant to disrupt routine political action. Realists, by contrast, argue for the need to combine in some fashion participatory and representative democracies. The ambiguous notion of an "anti-party party" is a reflection of the theoretical and practical uncertaintities surrounding this goal of fusion. At a very pragmatic level, the realists ultimately will have to define their relationship to the Social Democratic Party (SPD).

(3) Linked to this is the assessment of the welfare state. Is it, as the fundamentalists would have it, merely a prop for capitalism, and therefore something that should not be defended, or is it, according to the realist position, the product of working class victories over capitalism, at least in part, and thus not only warranting preservation, but expansion? The realist position introduces a need to re-think the response to bureaucracy. By endorsing the welfare state, a simple anti-bureaucratic ethos is inadequate; its reality in the modern world must be granted and its potential for reform must be explored.

(4) Another critical arena of dispute addresses the role of nation states in international politics and raises the issue of various options for promoting the demands of the peace movement. Is the movement to be construed as pacifist in all circumstances or not? In other words, should the movement, to use Weber's distinction, pursue an ethic of ultimate ends or an ethic of responsibility? Should it demand unilateral disarmament? Beyond the issue of warfare, what is the appropriate understanding of citizenship and sovereignty in modern nation states?

(5) A final query involves an understanding of the essential nature of progressive social movements. Should the Greens be seen as a unified, comprehensive movement or as an umbrella that shields a congeries of single-interest movements? Unlike the other issues, this cannot be divided into fundamentalist and realist positions. It raises questions about the life-cycle of social movements and conditions for success--in short, questions that must be raised by self-limiting, self-reflexive social movements.

And, if as Touraine suggests, social scientists have a potential role to play in elucidating the forms and contents of various modes of social change, the theoretical and praxiological issues for movement participants also constitute a research agenda for sociology. 


\section{REFERENCES}

Abendroth, Wolfgang

1972 A Short History of the European Working Class. New York Monthly Review Press.

Alberoni, Francesco

1984 Movement and Institution. New York: Columbia University Press.

Alford, C. Fred

1985 Science and the Revenge of Nature. Gainesville, FL: Bahro, Rudolf University Presses of Florida.

1984 From Red to Green. London: Verso Books.

Bell, Daniel

1973 The Coming of Post-Industrial Society. New York: Basic Books.

Bensman, Joseph and Arthur Vidich

1971 The New American Society. Chicago: Quadrangle Books.

Birnbaum, Norman

1969 The Crisis of Industrial Society. New York: Oxford

Boggs, Carl University Press.

1986 Social Movements and Political Power. Philadelphia:

Boyte, Harry Temple University Press.

1980 The Backyard Revolution. Philadelphia: Temple University Press.

Capra, Fritjof and Charlene Spretnak

1984 Green Politics. New York: E.P. Dutton.

Cohen, Jean

1983 . "Rethinking Social Movements." Berkeley Journal of Sociology 28:97-113.

1985 "Strategy or Identity: New Theoretical Paradigms and Contemporary Social Movements." Social Research 52:663716.

Cohen, Jean and Andrew Arato

1984 "The German Green Party." Dissent (Summer):327-332.

Delgado, Gary

1986 Organizing the Movement. Philadelphia: Temple Eder, Klaus University Press.

1985 "The 'New Social Movements': Moral Crusades, Political Pressure Groups, or Social Movements?" Social Research 52:867-890
Form, William

1985 Divided We Stand. Urbana, IL: University of Illinois Press.

Gamson, William

1975 The Strategy of Social Protest. Homewood, IL: Dorsey.

Giddens, Anthony

1973 The Class Structure of the Advanced Societies. New York: Harper and Row.

Goldthorpe, John and David Lockwood

1963 "Affluence and the British Class Structure." The Sociological Review 11:133-163.

Gorz, Andre

1973 Socialism and Revolution. Garden City, NY: Anchor Books.

1982 Farewell to the Working Class. Boston: South End Press.

Gouldner, Alvin

1979 The Future of Intellectuals and the Rise of the New Class. New York: The Seabury Press.

Habermas, Jurgen

1970 Toward a Rational Society. Boston: Beacon Press.

1975 Legitimation Crisis. Boston: Beacon Press.

Hobsbawm, Eric

1984 Workers: Worlds of Labor. New York: Pantheon Books.

Horkheimer, Max and Theodor Adorno

1972 The Dialectic of Enlightenment. New York: The Seabury Press.

Jenkins, J. Craig

1983 "Resource Mobilization Theory and the Study of Social Movements." Annual Review of Sociology 9:527-553.

1985 The Politics of Insurgency. New York: Columbia University Press.

1986 "Interpreting the Stormy Sixties: Three Theories in Search of a Political Age" (unpublished xerox)

Kann, Mark

1986 Middle Class Radicalism in Santa Monica. Philadelphia: Temple University Press.

Kivisto, Peter

1984 "Contemporary Social Movements in Advanced Industrial Societies and Sociological Intervention." Acta Sociologica 27:355-366.

Klandermans, Bert and Dirk Oegema

1987 "Potentials, Networks, Motivations and Barriers: Steps Towards Participation in Social Movements." American Sociological Review 52:519-531. 
New Social Movements and Socialism

Poulantzas, Nicos

1975 Classes in Contemporary Capitalism. London: New Left Books.

Smelser, Neil

1963 Theory of Collective Behavior. New York: The Free Press.

Smith, Anthony

1981 The Ethnic Revival in the Modern World. Cambridge: Cambridge University Press.

Szymanski, Albert

1978 The Capitalist State and the Politics of Class. Cambridge, MA: Winthrop.

Thompson, E.P.

1963 The Making of the English Working Class. New York: Vintage Books.

Tilly, Charles

1975 The Formation of National States in Western Europe. Princeton, NJ: Princeton University Press.

1978 From Mobilization to Revolution. Reading, MA: AddisonWesley.

Touraine, Alain

1971a The May Movement. New York: Random House.

$1971 \mathrm{~b}$ Post-Industrial Society. New York: Random House.

1981 The Voice and the Eye. Cambridge: Cambridge University Press.

Useem, Michael

1975 Protest Movements in America. Indianapolis, IN: BobbsMerrill.

Wright, Erik Olin

1985 Classes. London: Verso Books.

1973 Social Conflicts and Social Movements. Englewood Cliffs, NJ: Prentice-Hall.

1978 "The Decline of the 1960s Movements." Research in Social Movements, Conflicts and Change 1:257-289.

Offe, Claus

1984 Contradictions of the Welfare State. Cambridge, MA: MIT Press.

1985 Disorganized Capitalism. Cambridge, MA: MIT Press.

Papadakis, Elim

1984 . The Green Movement in West Germany. London: Croon Helm.

Perrow, Charles

1979 "The Sixties Observed." Pp. 192-211 in Meyer Zald and John McCarthy (eds.) The Dynamics of Social Movements. Cambridge, MA: Winthrop. 